\section{Proximate Cause}

Robert L. Heilbronner

Chicago Neuropsychology Group, Chicago, IL, USA

\section{Definition}

Proximate cause is used in tort law to link negligence to liability for an injury caused by an accident. The accident and injury must be shown to be the natural and probable result or consequence of the act(s) of negligence alleged by the attorneys to have been committed. The attorney for the plaintiff must prove that any negligence (no matter how small) of which the defendant is accused proximately caused the accident and his or her injuries. A defense attorney must at the same time prove that any contributory negligence of the plaintiff proximately caused the accident and any injuries of which the plaintiff complains and they were not primarily caused by the defendant. The traditional method of determining whether one event (e.g., car accident) is the proximate cause of another (traumatic brain injury) is to ask whether one could "reasonably foresee" that the former would lead to the latter. The concept has also been defined as "the conduct or thing, which, in the ordinary unbroken sequence of events, without a new factor intervening, produces injury, and but for which that injury would not have occurred." There may be more than one proximate cause of an accident. Multiple acts of negligence by different people may occur to cause the same accident, yet each may be deemed to be a proximate cause of the accident. Sometimes, there is an intervening cause (e.g., failure to comply with treatment recommendations in a personal injury case) that comes after the original negligence of the defendant and the injured plaintiff, which will then reduce the amount of the defendant's liability. If it is determined that this intervening cause (e.g., a second unrelated accident) is the substantial reason for the injury, then the defendant will not be liable at all.

\section{Cross-References}

Litigation

\section{References and Readings}

Melton, G. B., Petrila, J., Poythress, N. G., \& Slobogin, C. (1997). Psychological evaluations for the courts: A handbook for mental health professionals and lawyers. New York: Guilford Press.

Young, G., \& Shore, R. (2007). Dictionary of terms related to causality, causation, law, and psychology. In G. Young, A. Kane, \& K. Nicholson (Eds.), Causality of psychological injury: Presenting evidence in court. New York: Springer Press. 